\title{
APLIKASI BIO-BALL UNTUK MEDIA BIOFILTER STUDI KASUS PENGOLAHAN AIR LIMBAH PENCUCIAN JEAN
}

\author{
Oleh : \\ Nusa Idaman Said \\ Kelompok Teknologi Pengelolaan Air Bersih dan Limbah Cair, Pusat Pengkajian dan Penerapan Teknologi \\ Lingkungan, BPPT
}

\begin{abstract}
The textile industry is one of the most popular industries in Indonesia. Although it's giving a positive value towards economic value, it also contributes a bed effect towards environmental quality. One of those industries is small-scale laundry industry located in Kelurahan Sukabumi Selatan, West of Jakarta. The lack of land and money, most of the jeans laundry industry throws away their wastewater straight to the river system without any process. The present study describes the application plastic media called bio-ball as a biofilter supporting media for treating of jeans laundry industry wastewater using combined anaerobic and aerobic process. The type of reactor that is used in this research is a continuous flow biological reactor which has total volume 195 litter and divided into 5 zones, i.e. presedimentation, 2 anoxic zone, aerobic zone and post sedimentation zone. Reactor effluent is recirculated into presedimentation zone with hydraulic recycle ratio (HRR) 1:1. Seeding is done in a natural way by directly flowing the domestic wastewater into reactor with retention time 72 hours, until a biofilm layer is formed on the surface of bio-ball media. Acclimatization is done gradually by replacing domestic with laundry jeans wastewater in 72 hours retention time, until domestic wastewater was $100 \%$ replaced, The main research were conducting by continuous operation under condition 72 hours, 48 hours and 24 hours retention time. The result of experiment shows that within the combined anaerobic and aerobic process using bio-ball plastic media under conditions 1 3 days retention time, the removal efficiency of COD $78-91 \%$, BOD $85-92 \%$, Total Suspended Solids (TSS) $80-93 \%$, and Colour $48-57 \%$ respectively. The longer retention time has resulted in higher removal efficiency.
\end{abstract}

Kata Kunci : Bio-ball, biofilter, pencucian jean, anaerob-aerob.

\section{PENDAHULUAN}

\subsection{Masalah Air Limbah Pencucian Jean}

Satu contoh kasus pencemaran lingkungan yang sangat berat adalah yang terjadi di Kelurahan Sukabumi Selatan, Kecamatan Kebon Jeruk, Jakarta Barat yang diakibatkan oleh air limbah industri kecil tekstil. Kelurahan ini mempunyai kepadatan penduduk cukup tinggi dan diwilayahnya terdapat 34 perusahaan pencucian jeans (Laundry) yang rata-rata membuang air limbahnya yang berwarna biru-hitam sebesar antara $15-90$ $\mathrm{m}^{3} /$ hari ke Kali Sekretaris yang mengalir melalui kelurahan tersebut. Lokasi indsutri pencucian jeans yang ada di Kelurahan Sukabumi Selatan, Kecamatan Kebon Jeruk, Jakarta Barat ditunjukkan seperti pada Gambar 1. Baik air limbah domestik maupun air limbah industri keduanya telah mencemari lingkungan, terutama air sungai dan air tanah.

Dengan demikian semakin bertambahnya penduduk dan industrialisasi yang tidak berwawasan lingkungan di Jakarta, telah mengakibatkan sulitnya mencegah terjadinya percepatan proses pencemaran lingkungan dan selanjutnya yang terjadi adalah penurunan kualitas lingkungan.

Industri pencelupan atau pencucian jeans termasuk salah satu industri yang sangat banyak mengeluarkan limbah cair. Namun, penanganan pengolahan limbah cair pada industri yang termasuk skala kecil umumnya kurang baik . Potensi pencemaran air buangan industri tekstil sangat bervariasi tergantung pada proses dan kapasitas produksi serta kondisi lingkungan tempat pembuangan, sehingga akibat pencemaran juga berbeda-beda.

Harus diakui bahwa masih banyak industri tekstil yang hingga saat ini belum atau kurang memperhatikan masalah air buangan bekas proses pengolahan tekstil hingga tidak mengherankan apabila kadang-kadang terjadi keluhan maupun protes dari masyarakat yang merasa terganggu oleh adanya air buangan tersebut. 
Industri pencucian jeans adalah industri pencucian yang mengembangkan kegiatan menjadi industri pencucican dan pelunturan. Keberadaan industri pencucian jean berkembang sejalan dengan meningkatnya komoditas pakaian jadi Indonesia. Dalam hal ini, industri pakaian jadi (konveksi) mengadakan kerjasama dengan industri pencucian.

Dalam melaksanakan kegiatan sehari-hari industri pencucian jeans tidak selalu mengadakan proses-proses seperti yang tersebut di atas. Tetapi, kegiatannya berdasarkan pesanan dari industri konveksi, misalnya industri konveksi hanya membutukan proses pencucian saja tanpa proses pencucian sekaligus proses pelunturan.

Oleh karena itu, perlu memasyarakatkan suatu penerapan teknologi pengolahan air limbah yang tepat dan murah untuk dapat mengatasi masalah pencemaran lingkungan secara cepat. Salah satu alternatif yakni pengolahan air limbah industri pencucian atau pencelupan tekstil dengan proses biologis yakni menggunakan teknologi biofilter anaerob-aerob.

\subsection{TUJUAN PENELITIAN}

Penelitian ini bertujuan untuk mengkaji efektifitas penggunaan bio-ball sebagai media biofilter untuk pengolahan air limbah industri pencucian atau pencelupan jeans dengan menggunakan proses biofilter anaerob-aerob tercelup.

\section{KAJIAN PUSTAKA}

\subsection{Proses Pencelupan Jean}

Berdasarkan proses kegiatannya, industri pencucian jeans dibagi menjadi beberapa jenis, yakni :

\section{Proses pencucian (Garment Wash)}

Proses ini bertujuan untuk membuang kanji dengan maksud melemaskan pakaian jeans yang masih kaku. Bahan yang di gunakan adalah air sebanyak 500 liter, detergen merk Blue-J Scour (cair dan berwarna coklat) sebanyak 250-300 ml dan sebagai bahan pengganti detergen dapat digunakan zat kimia Genencor Desize-HT (cair dan berwarna biru) sebanyak $1,5 \mathrm{Kg}$. Pada proses Garment Wash ini suhu diusahakan $40^{\circ} \mathrm{C}-50^{\circ} \mathrm{C}$ dan pakaian digiling dalam mesin selama 25 menit. Apabila pihak konsumen hanya membutuhkan pencucian saja, maka proses selanjutnya tidak dilakukan.

\section{Proses Pelunturan}

Setelah proses pelemasan atau pencucian, kemudian dilakukan proses pelunturan atau pemucatan jeans dengan maksud melunturkan warna asli jeans menjadi warna dasarnya atau lebih pucat dari warna aslinya. Proses ini dilakukan tergantung permintaan. Proses pelunturan ada dua macam, yakni:

(a) Proses Stone Wash, yaitu proses pelunturan warna pakaian jadi jeans dengan menggunakan bahan yang sama dengan batu apung sebagai bahan penggosok atau peluntur.

(b) Proses Stone Bleanching, yaitu proses pelunturan warna pakaian jadi selain menggunakan bahan yang sama dengan stone wash juga ditambah dengan Sodium hipochlorite yang berfungsi untuk pemutih. Penggunaan Sodium hipochlorite ini tidak banyak tentunya tergantung permintaan (sesuai dengan warna putih yang di inginkan).

\section{Proses pembilasan}

Setelah proses pencucian dan pelunturan maka dilakuakan proses pembilasan dimana dalam proses ini diperlukan air sebanyak 500 liter, softener sebagai pelembut sebanyak $0,6 \mathrm{ml}$ dan OBA untuk mencerahkan warna sebanyak $0,3 \mathrm{ml}$. Suhu disesuaikan tetap $30^{\circ} \mathrm{C}$ dan dapat diputar selama 10 menit. Sedangkan untuk proses pembilasan dimana dalam proses pembilasan yang berasal dari Stone Bleancing selain bahan-bahan di atas, ditambahkan pula Sodium hipochlorite dan mengilangkan bau sebanyak $1 \mathrm{Kg}$ per mesin serta Hidrogen perioksida $\left(\mathrm{H}_{2} \mathrm{O}_{2}\right)$ yang berfungsi untuk membuat bersih atau warna terang sebanyak $1 \mathrm{~kg}$.

\section{Proses Pemerasan}

Proses pemerasan adalah proses untuk menghilangkan air dari pakaian jadi jeans. Proses ini bertujuan untuk mempercepat proses pengeringan. Pada proses pemerasan ini digunakan mesin ekstrator yang berkapasitas 30 - 40 potong pakaian yang diputar selama 5 menit.

\section{Proses Pengeringan}

Proses pengeringan adalah proses yang dilakukan setelah pakaian jadi telah mengalami proses pembilasan dengan maksud untuk mengeringkan pakaian jadi jeans. Proses pengeringan dapat dilakukan melalui penjemuran dengan sinar matahari maupun menggunakan mesin pengering berupa oven 
yang berkapasitas 50-70 potong pakaian. proses ini memerlukan waktu sekitar 45 menit - 1 jam.

\section{Proses pewarnaan}

Pada proses ini pakaian jadi jeans diberi warna sesuai dengan permintaan, dengan menggunakan bahan-bahan kimia. Hasil sampingan dari proses kegiatan industri pencucian jeans adalah limbah yang dihasilkan dari proses pencucian jeans.

Limbah pencucian jeans secara fisik berwarna biru atau ungu berbau kaporit yang menyengat serta terdapat busa berwarna. Selain itu ada zat-zat tersuspensi dari batu apung yang hancur dari proses pelunturan banyak mengendap di saluran air sehingga menyebabkan pendangkalan. seperti limbah industri lainnya, limbah pencucian jeans ini dapat menimbulkan gangguan terhadap manusia, biota air maupun gangguan estetika.

\subsection{Proses Biofilm Atau Biofilter Tercelup (Submerged Biofilm)}

Proses pengolahan air limbah dengan proses biofilm atau biofilter tercelup dilakukan dengan cara mengalirkan air limbah ke dalam reaktor biologis yang di dalamnya diisi dengan media penyangga untuk pengebangbiakan mikroorganisme dengan atau tanpa aerasi. Untuk proses anaerobik dilakukan tanpa pemberian udara atau oksigen. Posisi media biofilter tercelup di bawah permukaan air.

Mekanisme proses metabolisme di dalam sistem biofilm secara aerobik secara sederhana dapat diterangkan seperti pada Gambar 2 . Gambar tersebut menunjukkan suatu sistem biofilm yang yang terdiri dari medium penyangga, lapisan biofilm yang melekat pada medium, lapisan alir limbah dan lapisan udara yang terletak diluar. Senyawa polutan yang ada di dalam air limbah, misalnya senyawa organik (BOD, COD), ammonia, fosfor dan lainnya akan terdifusi ke dalam lapisan atau film biologis yang melekat pada permukaan medium. Pada saat yang bersamaan dengan menggunakan oksigen yang terlarut di dalam air limbah, senyawa polutan tersebut akan diuraikan oleh mikroorganisme yang ada di dalam lapisan biofilm dan energi yang dihasilkan akan diubah menjadi biomasa. Sulpai oksigen pada lapisan biofilm dapat dilakukan dengan beberapa cara misalnya pada sistem RBC, yakni dengan cara kontak dengan udara luar pada sistem "Trickling Filter" dengan aliran balik udara. Sedangkan pada sistem biofilter tercelup, dengan menggunakan blower udara atau pompa sirkulasi.

Jika lapiasan mikrobiologis cukup tebal, maka pada bagian luar lapisan mikrobiologis akan berada dalam kondisi aerobik sedangkan pada bagian dalam biofilm yang melekat pada medium akan berada dalam kondisi anaerobik. Pada kondisi anaerobik akan terbentuk gas $\mathrm{H}_{2} \mathrm{~S}$, dan jika konsentrasi oksigen terlarut cukup besar, maka gas $\mathrm{H}_{2} \mathrm{~S}$ yang terbentuk tersebut akan diubah menjadi sulfat $\left(\mathrm{SO}_{4}\right)$ oleh bakteri sulfat yang ada di dalam biofilm.

Selain itu, pada zona aerobik nitrogenammonium akan diubah menjadi nitrit dan nitrat dan selanjutnya pada zona anaerobik nitrat yang terbentuk mengalami proses denitrifikasi menjadi gas nitrogen. Karena di dalam sistem bioflim terjadi kondisi anaerobik dan aerobik pada saat yang bersamaan, maka dengan sistem tersebut proses penghilangan senyawa nitrogen menjadi lebih mudah. Hal ini secara sederhana ditunjukkan seperti pada Gambar 2.

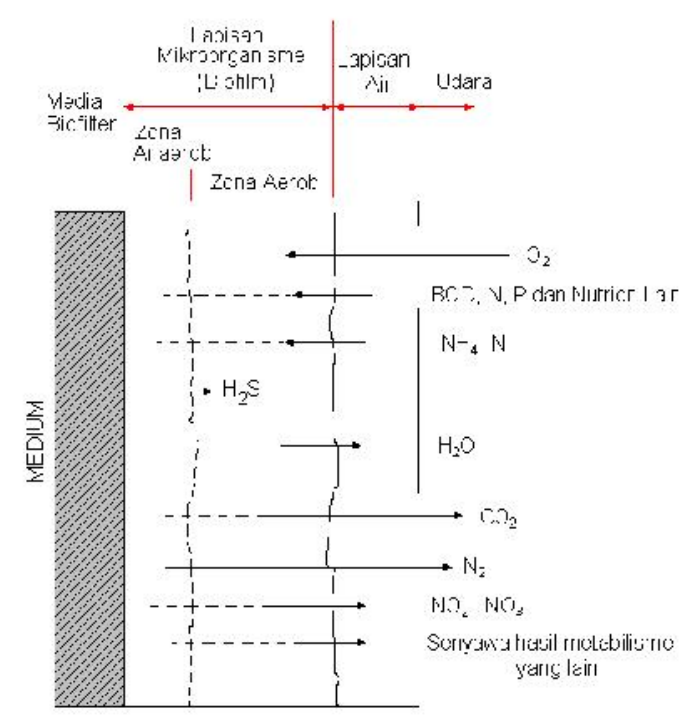

Gambar 2 : Mekanisme proses metabolisme di dalam sistem biofilm.

\subsection{Media Biofilter}

Media biofilter yang digunakan secara umum dapat berupa bahan material organik atau bahan material anorganik. Untuk media biofilter dari bahan organik misalnya dalam bentuk tali, bentuk jaring, bentuk butiran tak teratur (random packing), bentuk papan (plate), bentuk sarang tawon dan lain-lain. Sedangkan untuk media dari bahan anorganik misalnya batu pecah (split), kerikil, batu marmer, batu tembikar, batu bara (kokas) dan lain sebagainya.

Di dalam proses pengolahan air limbah dengan sistem biofilter tercelup aerobik, sistem suplai udara dapat dilakukan dengan berbagai cara. Beberapa cara yang sering digunakan antara lain aerasi samping, aerasi tengah (pusat), aerasi merata seluruh permukaan, aerasi eksternal, aerasi dengan "air lift pump", 
dan aerasi dengan sistem mekanik. Masingmasing cara mempunyai keuntungan dan kekurangan. Sistem aerasi juga tergantung dari jenis media maupun efisiensi yang diharapkan. Penyerapan oksigen dapat terjadi disebabkan terutama karena aliran sirkulasi atau aliran putar, kecuali pada sistem aerasi merata seluruh permukaan media.

Di dalam proses biofilter dengan sistem aerasi merata, lapisan mikroorganisme yang melekat pada permukaan media mudah terlepas, sehingga seringkali proses menjadi tidak stabil. Tetapi, di dalam sistem aerasi melalui aliran putar, kemampuan penyerapan oksigen hampir sama dengan sistem aerasi dengan menggunakan difuser. Oleh karena itu, untuk penambahan jumlah beban yang besar sulit dilakukan. Berdasarkan hal tersebut, belakangan ini penggunaan sistem aerasi merata banyak dilakukan karena mempunyai kemampuan penyerapan oksigen yang besar.

Jika kemampuan penyerapan oksigen besar, maka dapat digunakan untuk mengolah air limbah dengan beban organik (organic loading) yang besar pula. Oleh karena itu, diperlukan juga media biofilter yang dapat melekatkan mikroorganisme dalam jumlah yang besar. Biasanya untuk media biofilter dari bahan anaorganik, semakin kecil diameternya, luas permukaannya semakin besar. Sehingga jumlah mikroorganisme yang dapat dibiakkan juga menjadi besar. Jika sistem aliran dilakukan dari atas ke bawah (down flow), maka sedikit banyak terjadi efek filtrasi sehingga terjadi proses peumpukan lumpur organik pada bagian atas media yang dapat mengakibatkan penyumbatan. Oleh karena itu, perlu proses pencucian secukupnya. Jika terjadi penyumbatan, maka dapat terjadi aliran singkat (Short pass) dan juga terjadi penurunan jumlah aliran sehingga kapasitas pengolahan dapat menurun secara drastis.

Media biofilter banyak yang dibuat dengan cara dicetak dari bahan tahan karat dan ringan, misalnya PVC dan lain sebagainya dengan luas permukaan spesifik yang besar dan volume rongga (porositas) yang besar sehingga dapat melekatkan mikroorganisme dalam jumlah yang besar dengan resiko kebuntuan yang sangat kecil. Dengan demikian, memungkinkan untuk pengolahan air limbah dengan beban konsentrasi yang tinggi serta efisiensi pengolahan yang cukup besar.

Salah satu contoh media biofilter yang banyak digunakan yakni media dalam bentuk bio-ball dan juga tipe sarang tawon (honeycomb tube) dari bahan PVC. Beberapa contoh perbandingan luas permukaan spesifik dari berbagai media biofilter dapat dilihat pada Tabel 1.
Tabel 1 : Perbandingan luas permukaan spesifik media biofilter.

\begin{tabular}{|c|l|c|}
\hline No. & \multicolumn{1}{|c|}{ Jenis Media } & $\begin{array}{c}\text { Luas permukaan } \\
\text { spesifik }\left(\mathrm{m}^{2} / \mathrm{m}^{3}\right)\end{array}$ \\
\hline 1 & $\begin{array}{l}\text { Trickling Filter } \\
\text { dengan batu pecah }\end{array}$ & $100-200$ \\
2 & $\begin{array}{l}\text { Modul Sarang Tawon } \\
\text { (honeycomb modul) }\end{array}$ & $150-240$ \\
3 & Tipe Jaring & 50 \\
4 & Bio-ball & $200-235$ \\
5 & RBC & $80-150$ \\
\hline
\end{tabular}

Media bio-ball mempunyai keunggulan antara lain mempunyai luas spesifik yang cukup besar, pemasangannya mudah (random), tidak memerlukan manhole yang besar sehingga untuk paket Instalasi Pengolahan Air Limbah (IPAL) kecil sangat sesuai.

Pengolahan air limbah dengan proses biofilter mempunyai beberapa keunggulan, antara lain :

\section{A. Pengoperasiannya mudah}

Di dalam proses pengolahan air limbah dengan sistem biofilm tanpa dilakukan sirkulasi lumpur, tidak terjadi masalah "bulking" seperti pada proses lumpur aktif (activated sludge process). Karena itu pengelolaannya sangat mudah.

\section{B. Lumpur yang dihasilkan sedikit}

Dibandingakan dengan proses lumpur aktif, lumpur yang dihasilkan pada proses biofilm relatif lebih kecil. Di dalam proses lumpur aktif antara 30\% - 60\% dari BOD yang dihilangkan (removal BOD) diubah menjadi lumpur aktif (biomasa) sedangkan pada proses biofilm hanya sekitar $10 \%-30 \%$. Hal ini disebabkan karena pada proses biofilm, rantai makanan lebih panjang dan melibatkan aktifitas mikroorganisme dengan orde yang lebih tinggi dibandingkan pada proses lumpur aktif.

\section{Dapat digunakan untuk pengolahan air limbah dengan konsentrasi rendah maupun konsentrasi tinggi.}

Karena di dalam proses pengolahan air limbah dengan sistem biofilm mikroorganisme atau mikroba melekat pada permukaan medium penyangga, maka pengontrolan terhadap mikroorganisme atau mikroba lebih mudah. Proses biofilm tersebut cocok digunakan untuk mengolah air limbah 
dengan konsentrasi rendah maupun konsentrasi tinggi.

D. Tahan terhadap fluktuasi jumlah air limbah maupun fluktuasi konsentrasi.

Di dalam proses biofilter, mikro-organisme melekat pada permukaan unggun media. Akibatnya, konsentrasi biomasa mikroorganisme per satuan volume relatif besar sehingga relatif tahan terhadap fluktuasi beban organik maupun fluktuasi beban hidrolik.

E. Pengaruh penurunan suhu terhadap efisiensi pengolahan kecil.

Jika suhu air limbah turun maka aktifitas mikroorganisme juga berkurang. Tetapi, karena di dalam proses biofilm substrat maupun enzim dapat terdifusi sampai ke bagian dalam lapisan biofilm dan juga lapisan biofilm bertambah tebal, maka pengaruh penurunan suhu (suhu rendah) tidak begitu besar.

\section{MATERIAL DAN METODA PENELITIAN}

\subsection{Material}

\subsection{A Air Limbah}

Air limbah yang digunakan untuk penelitian diambil dari air limbah yang dihasilkan oleh salah satu industri pencucian jeans, di Kelurahan Sukabumi Selatan, Jakarta Selatan.

\subsection{B Media Biofilter}

Media biofilter yang digunakan adalah media dari bahan plastik PVC tipe bio-ball dengan spesifikasi seperti pada Tabel 2, sedangkan bentuk media bio-ball dapat dilihat seperti pada Gambar 3.

Tabel 2 : Spesifikasi media Sarang Tawon yang digunakan untuk percobaan.

$\begin{array}{lll}\text { Tipe } & : & \text { Bio-ball } \\ \text { Material } & : & \text { PVC } \\ \text { Bentuk } & : & \text { bola } \\ \text { Ukuran } & : & \text { Diameter } 4 \mathrm{~cm} \\ \text { Luas Spesifik } & : & \pm 230 \mathrm{~m}^{2} / \mathrm{m}^{3} \\ \text { Porositas Ronga } & : & 0,92 \\ \text { Warna } & : & \text { Hitam }\end{array}$

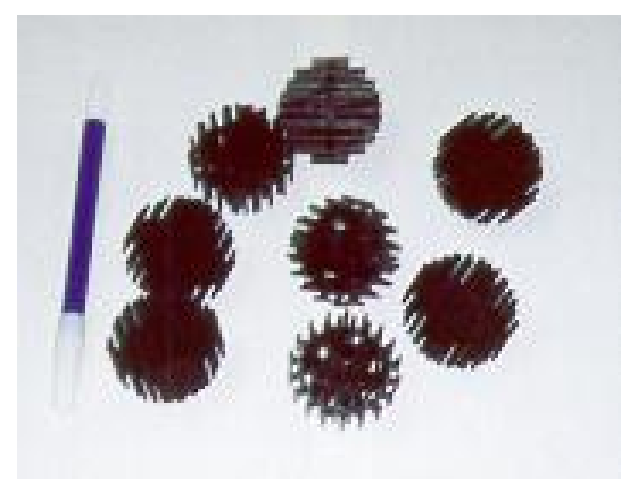

Gambar 3 : Media Bio-ball yang digunakan untuk percobaan.

\subsection{Percobaan}

\section{A. Model Reaktor}

Pengolahan air limbah dilakukan dengan cara mengoperasikan reaktor biologis yang terdiri dari bak pengendapan awal, biofilter anaerob, biofilter aerob serta bak pengendapan akhir. Skema proses pengolahan serta ukuran reaktor ditunjukkan seperti pada Gambar 4. Lebar reaktor $30 \mathrm{~cm}$, panjang reaktor $130 \mathrm{~cm}$ dan tinggi $50 \mathrm{~cm}$. Spesifikasi reaktor dan perlengkapannya ditunjukkan seperti pada Tabel 3.

Tabel 3 : Spesifikasi Reaktor biofilter dan Perlengkapannya yang digunakan untuk percobaan.

\begin{tabular}{|c|c|}
\hline URAIAN & KETERANGAN \\
\hline $\begin{array}{l}\text { REAKTOR : } \\
\text { Bahan } \\
\text { Tinggi } \\
\text { Panjang } \\
\text { Lebar } \\
\text { Volume } \\
\end{array}$ & $\begin{array}{l}\text { Kaca, diameter } 6 \mathrm{~mm} \\
50 \mathrm{~cm} \\
130 \mathrm{~cm} \\
25 \mathrm{~cm} \\
195 \text { liter }\end{array}$ \\
\hline 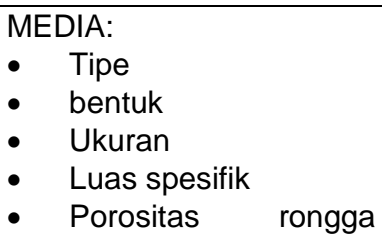 & $\begin{array}{l}\text { Bio-ball } \\
\text { Bulat/bola } \\
\text { Diameter } 4 \mathrm{~cm} \\
200-230 \mathrm{~m}^{2} / \mathrm{m}^{3} \\
0,92\end{array}$ \\
\hline PIPA INLET dan OUTLET & $\begin{array}{l}\text { PVC, diameter } 0,5 \\
\text { inchi }\end{array}$ \\
\hline $\begin{array}{l}\text { AERATOR : } \\
\text { Suplai udara }\end{array}$ & 1,105 L/menit \\
\hline $\begin{array}{l}\text { POMPA SIRKULASI : } \\
\text { Debit }\end{array}$ & 900 liter/menit \\
\hline $\begin{array}{l}\text { RESERVOIR : } \\
\text { Bahan } \\
\text { Volume }\end{array}$ & $\begin{array}{l}\text { Plastik } \\
200 \text { liter }\end{array}$ \\
\hline $\begin{array}{ll}\text { BAK PEMBUBUHAN : } \\
\text { - } \quad \text { Bentuk } \\
\text { - } \quad \text { Bahan } \\
\text { - } \quad \text { Ukuran }\end{array}$ & $\begin{array}{l}\text { Buffle Channel } \\
\text { Kaca } \\
40 \times 30 \times 65 \mathrm{~cm}\end{array}$ \\
\hline
\end{tabular}


Air limbah di tampung ke dalam tangki penampung, selanjutnya dialirkan ke bak pengendapan awal. Dari bak pengendapan awal, air limbah dialirkan ke biofilter anaerob. Biofilter anaerob terdiri dari dua ruangan yang diisi dengan media plastik bio-ball. Arah aliran di dalam biofilter anaerob adalah dari atas ke bawah dan dari bawah ke atas. Air limpasan dari biofilter anaerob selanjutnya masuk ke biofilter aerob. Di dalam biofilter aerob juga diisi dengan media bio-ball dengan arah aliran dari atas ke bawah, sambil dihembus dengan udara menggunakan blower. Selanjutnya, air limbah masuk ke bak pengendapan akhir melalui bagian bawah bak. Air limbah di dalam bak pengendapan akhir sebagian disirkulasi ke biofilter aerob dengan rasio sirkulasi hidrolik (Hydaulic Recycle Ratio, HRR ) sama dengan 1 (satu). Air limpasan dari bak pengendapan akhir merupakan air olahan.

\section{B. Proses Pengembangbiakan Mikroorganisme (Seeding)}

Pengembangbiakan mikroorganisme atau disebut juga seeding dilakukan untuk menumbuhkan mikroorganisme. Seeding yang dilakukan adalah seeding secara alami dengan cara mengalirkan air limbah domestik secara kontinyu ke dalam reaktor biofilter. Penggunaan air limbah domestik dikarenakan air buangan ini kaya akan mikroorganisme dan telah mempunyai sumber karbon yang cukup sehingga pertumbuhan mikroorganisme pada media akan menjadi cepat. Pemberian tambahan karbon dari glukosa hanya diberikan sewaktu-waktu. Pada saat konsentrasi COD limbah domestik rendah, glukosa tidak diberikan setiap hari. Dalam proses ini telah terbentuk lapisan biofilm yang menyelimuti media sarang tawon.

\section{Adaptasi atau Aklimatisasi}

Aklimatisasi adalah pengadaptasian mikroorganisme terhadap air buangan yang akan diolah. Pengadaptasian dilakukan dengan cara mengganti air limbah domestik secara perlahan dengan air limbah dari industri pewarnaan jeans. Lapisan biofilm yang terbentuk akan semakin menebal. Akhir dari aklimatisasi adalah ketika air buangan domestik telah $100 \%$ tergantikan dengan air buangan pencucian jeans dan efisiensi penurunan konsentrasi COD yang cukup tinggi dan stabil. Tahapan proses aklimatisasi dapat dilihat pada Tabel 4.

\section{Prosedure Percobaan}

Setelah proses aklimatisasi berjalan stabil, percobaan dilakukan dengan skenario 3 jenis waktu tinggal, yaitu 72 jam (3 hari), 48 jam (2 hari) dan 24 jam (1 hari). Hal ini berarti debit yang akan dialirkan ke dalam reaktor untuk tiap tiap waktu tinggal adalah seperti pada Tabel 5 .

Tabel 4 : Tahapan aklimatisasi

\begin{tabular}{|c|c|c|}
\hline Tahapan & $\begin{array}{c}\text { Air limbah } \\
\text { domestik (\%) }\end{array}$ & $\begin{array}{c}\text { Air limbah } \\
\text { pewarnaan jeans } \\
(\%)\end{array}$ \\
\hline Tahap I & 90 & 10 \\
\hline Tahap II & 80 & 20 \\
\hline Tahap III & 70 & 30 \\
\hline Tahap IV & 60 & 40 \\
\hline Tahap V & 50 & 50 \\
\hline Tahap VI & 40 & 60 \\
\hline Tahap VII & 30 & 70 \\
\hline Tahap VIII & 20 & 80 \\
\hline Tahap IX & 10 & 90 \\
\hline Tahap X & 0 & 100 \\
\hline
\end{tabular}

Tabel 5 : Variasi Waktu Tinggal dan Debit Air Baku

\begin{tabular}{|c|c|}
\hline Waktu Tinggal (jam) & Debit (liter/menit) \\
\hline 72 & 0,0451 \\
\hline 48 & 0,0677 \\
\hline 24 & 0,136 \\
\hline
\end{tabular}

Percobaan dilakukan dengan proses biofilter tanpa pengaturan $\mathrm{pH}$, dan dilakukan pada kondisi suhu kamar. Skema proses percobaan pertama dapat dilihat seperti pada Gambar 4.

Pengambilan contoh (sampling) dilakukan pada titik-titik tertentu yang kemudian akan dianalisa parameternya. Titik pengambilan contoh adalah sebagai berikut :

- Titik 1 : Influen

- Titik 2 : Efluen Zona Anoksik

- Titik 3 : Efluen reaktor (yang akan dibuang ke perairan)

Pengambilan sampel dilakukan ketika kondisi reaktor telah stabil. Penentuan kondisi stabil dilakukan dengan mengukur kandungan organik (COD) pada setiap titik sampling tersebut.

\section{E. Analisa Parameter}

Di dalam penelitian ini parameter yang akan diukur adalah :

1) Kebutuhan Oksigen Kimiawi (COD), yaitu untuk mengetahui jumlah oksigen yang diperlukan untuk menguraikian senyawa organik secara kimiawi. Analisa untuk pengukuran parameter ini yang digunakan adalah metode bikromat $\left(\mathrm{K}_{2} \mathrm{Cr}_{2} \mathrm{O}_{7}\right)$ secara open refluks.(Standart Method No. 5220 C) 


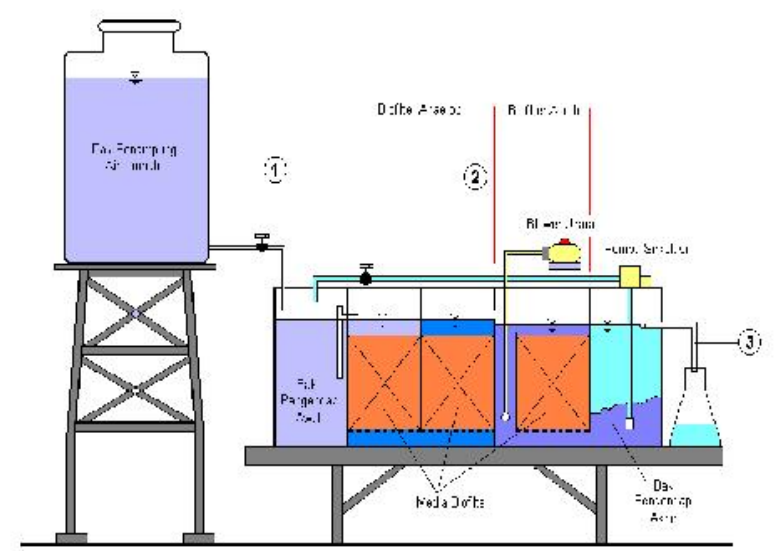

Gambar 4 : Diagram proses pengolahan air limbah pencucian jean dengan proses biofilter.

2) Padatan tersuspensi (TSS), dapat berupa senyawa organik dan anorganik. Dekomposisi padatan yang tersuspensi ini akan meningkatkan nilai BOD dan COD, hingga akhirnya dapat menurunkan DO di perairan. Untuk menganalisa parameter ini metode yang digunakan adalah metode gravimetri dengan kertas saring. (Standart Method No. 2540 D)

3) Warna. Air yang mempunyai warna yang bukan warna alami akan mengganggu estetika dan penyerapan sinar matahari untuk kehidupan ekosistem perairan tersebut. Warna yang pekat dari air buangan umumnya disebabkan karena kandungan organik yang tinggi dan banyaknya padatan yang tersuspensi. Analisa parameter untuk pengukuran parameter ini adalah dengan metode kolorimetri menggunakan spektrofotometer. (Standart Method No. 2120 C)

\section{HASIL PERCOBAAN}

Secara garis besar, kegiatan yang dilakukan dalam penelitian ini terbagi atas 3 tahapan kegiatan, yaitu tahap seeding (pembenihan), tahap aklimatisasi dan tahap penelitian berdasarkan waktu tinggal hidrolis (WTH). Percobaan meliputi tahap seeding, tahap aklimatisasi, kinerja biofilter dalam penghilangan COD, TSS dan warna. Sebelum penelitian dilaksanakan, terlebih dahulu dilakukan penelitian pendahuluan terhadap air limbah pencucian jeans untuk mengetahui karakteristik limbah tersebut. Secara umum karakteristik limbah pencucian jeans dapat dilihat pada Tabel 6 .
Tabel 6 : Karakteristik limbah pencucian jeans.

\begin{tabular}{|c|c|c|c|}
\hline No & Parameter & Satuan & Konsentrasi \\
\hline 1 & BOD & $\mathrm{mg} / \mathrm{l}$ & $400-1215$ \\
\hline 2 & $\mathrm{COD}$ & $\mathrm{mg} / \mathrm{l}$ & $910-1612$ \\
\hline 3 & TSS & $\mathrm{mg} / \mathrm{l}$ & $475-550$ \\
\hline 4 & Warna & $\mathrm{Pt} . \mathrm{Co}$ & $>500$ \\
\hline 5 & $\mathrm{pH}$ & - & $6,0-6,8$ \\
\hline
\end{tabular}

Sumber : Hasil penelitian

\subsection{Hasil Pembiakan Mikroba (Seeding)}

Seeding atau disebut juga sebagai pembiakan mikroba merupakan langkah awal dari penelitian reaktor biologis. Dalam tahapan ini dilakukan upaya untuk menumbuhkan mikroorganisme pada media penyokong. Mikroorganisme ini sangat berperan penting dalam proses pengolahan biologis ini. Di dalam penelitian ini, seeding dilakukan secara alami, yaitu dengan langsung membiakkan mikroorganisme di dalam reakor dengan cara mengalirkan air limbah domestik secara kontinyu ke dalam reaktor. Air limbah domestik dipilih untuk pembiakan ini dikarenakan limbah domestik kaya akan sumber karbon yang diperlukan mikroorganisme untuk hidup dan juga di dalam air tersebut terkandung berbagai mikroorganisme. Dengan demikian, proses pembiakan tidak perlu memakan waktu terlalu lama. Walaupun demikian, sumber karbon yang diperlukan tetap dijaga dengan sesekali memberikan penambahan glukosa.

Di dalam proses seeding ini air buangan domestik yang memang telah banyak mengandung bakteri dialirkan secara kontinyu ke dalam reaktor biofilter dan secara bersamaan aerator juga dijalankan. Setelah lapisan lendir atau biofilm telah tumbuh dapat dilakukan aklimatisasi. Di dalam penelitian ini proses seeding dilakukan dengan waktu tinggal hidrolis di dalam reaktor 72 jam (3 hari). Dengan kondisi waktu tinggal yang cukup di dalam reaktor, maka mikroorganisme dengan cepat berkembang biak dan melekat pada permukaan media bio-ball.

Pertumbuhan mikroorganisme pada media dapat dilihat dari peningkatan efisiensi penghilangan COD. Efisiensi yang meningkat menunjukkan adanya aktifitas mikroorganisme yang telah tumbuh semakin banyak dan mendegradasi senyawa organik yang ada di dalam air buangan tersebut. Dalam hal ini VSS tidaklah menjadi parameter utama karena proses seeding dilakukan secara langsung pada reaktor dan mikroorganisme yang ada langsung melekat pada media membentuk lapisan biofilm.

Hasil seeding dapat dilihat seperti pada Gambar 5. 


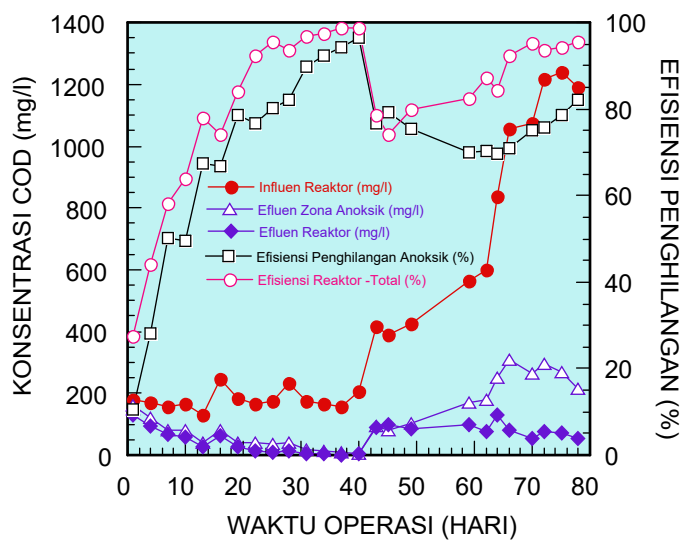

Gambar 5 : Penurunan konsentrasi dan efisiensi penghilangan COD selama proses pembiakan mikroba (seeding)

Dari gambar tersebut terlihat bahwa pada minggu pertama penghilangan COD baru mencapai sekitar $58 \%$. Hal ini terjadi karena pada saat pengoperasian awal belum terbentuk lapisan biofilm yang berarti mikroorganisme belum banyak yang menempel pada media.

Setelah pengoperasian seeding berjalan selama satu bulan, lapisan biofilm mulai terlihat menebal dan efisiensi penghilangan COD sudah mulai tinggi, yakni mencapai lebih dari $90 \%$. Tetapi konsentrasi air limbah domestik yang dimasukkan ke dalam reaktor sekitar $150 \mathrm{mg} / \mathrm{l}$. Hal ini masih sangat kecil dibandingan dengan konsentrasi COD air limbah pencucian jeans yang akan diolah. Untuk menaikan konsentrasi zat organik di dalam air limbah, maka setelah operasi berjalan 40 hari dilakukan penambahan larutan glukose ke dalam air limbah secara bertahan sampai konsentrasi COD yang masuk reaktor sama dengan konsentrasi COD air limbah pencucian jeans.

Setelah operasi berjalan 70 hari efisiensi telah mencapai $95 \%$, yakni konsentrasi COD di dalam influen reaktor $1074,7 \mathrm{mg} / \mathrm{l}$ setelah diolah turun menjadi $52,7 \mathrm{mg} / \mathrm{l}$. Hal ini sebenarnya telah sesuai untuk dilanjutkan ke proses adaptasi tetapi untuk itu harus dijaga agar kondisi ini tetap stabil. Kondisi stabil dicapai setelah 78 hari, yaitu dimana efisiensi penghilangan COD mencapai kira-kira $95 \%$. Dengan demikian proses aklimatisasi dapat dilakukan.

\subsection{Hasil Aklimatisasi}

Setelah mikroorganisme yang tumbuh cukup banyak (hal ini terlihat pada ketebalan biofilm) dan efisiensi penghilangan COD telah tinggi dan stabil, maka dapat dilakukan proses pengadaptasian atau disebut juga aklimatisasi.

Aklimatisasi dilakukan dengan waktu tinggal 72 jam dan dilakukan dengan cara mengganti secara bertahap air limbah domestik yang digunakan pada waktu seeding dengan air limbah pencucian jeans. Penggantian ini dilakukan dengan perbandingan 10\% limbah pencucian jeans dan $90 \%$ limbah domestik yang kemudian secara bertahap akan menjadi $100 \%$ air limbah pencucian jeans. Titik akhir aklimatisasi dicapai ketika efisiensi penghilangan COD telah stabil pada saat air limbah domestik telah $100 \%$ tergantikan dengan air limbah pewarnaan jeans. Hasil proses aklimatisasi secara lengkap dapat dilihat pada Gambar 5.

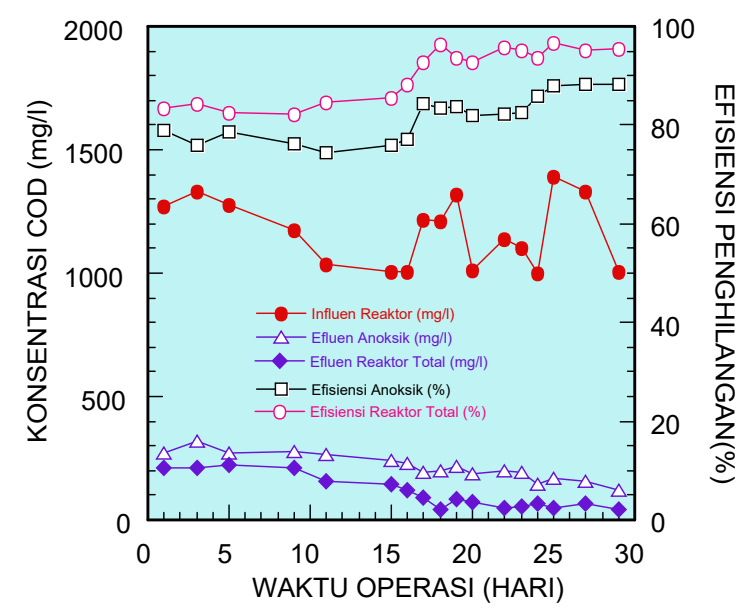

Gambar 5 : Penurunan konsentrasi dan efisiensi penghilangan COD selama proses aklimatisasi.

Dari gambar 5 tersebut dapat dilihat pada saat perbandingan limbah pencucian jeans dengan limbah domestik 10\%:90\%, konsentrasi COD di dalam influen $1270 \mathrm{mg} / \mathrm{l}$ dan efisiensi pengilangan COD mencapai $83,5 \%$. Pada saat influen $100 \%$ limbah pencucian jeans yakni setelah waktu operasi 27 hari, konsentrasi COD di dalam influen $1332 \mathrm{mg} / \mathrm{l}$ dan efisiensi penghilangan COD 95\%. Proses berjalan stabil setelah aklimatisasi berjalan selama 291 hari dengan efisiensi penghilangan COD sekitar $95 \%$.

\subsection{Hasil Percobaan Variasi Waktu Tinggal}

\subsubsection{Penghilangan Senyawa Organik (COD)}

Setelah proses aklimatisasi berjalan dengan baik yaitu diindikasikan dengan semakin meningkatnya efisiensi penghilangan $\mathrm{COD}$ dan limbah domestik telah 100\% tergantikan dengan limbah pewarnaan jeans, maka pengoperasian secara kontinyu dapat dilakukan. Dalam pengoperasian kontinyu ini, sampling parameter BOD, COD dilakukan pada 3 titik pengambilan sampel. Proses dalam biofilter dikatakan telah berada dalam kondisi stabil (steady state) jika biofilm tumbuh dengan baik dan efisiensi penghilangan relatif konstan. Dalam peng- 
operasian kontinyu ini, debit air limbah disesuaikan dengan waktu tinggal yang dipilih. Waktu tinggal yang dipilih adalah 72 jam, 48 jam dan 24 jam. Pengoperasian diawali dari waktu tinggal 72 jam hingga yang terpendek 24 jam. Efisiensi penghilangan COD untuk setiap waktu tinggal dapat Gambar 6.

Dari hasil tersebut terlihat untuk waktu tinggal hidrolis (WTH) 72 jam konsentrasi COD di dalam influen rata-rata $1146 \mathrm{mg} / \mathrm{l}$ sedangkan konsentrasi COD di dalam efluen turun mencapai rata-rata 91,5 mg/l, dengan efisiensi penghilangan COD rata-rata mencapai 91,5\%. Untuk waktu tinggal hidrolis 48 jam konsentrasi COD di dalam influen rata-rata $1194 \mathrm{mg} / \mathrm{l}$ sedangkan konsentrasi rata-rata COD di dalam efluen turun menjadi sekitar 232,1 $\mathrm{mg} / \mathrm{l}$ dengan efisiensi penghilangan COD rata-rata menjadi sekitar 80,5 \%. Untuk waktu tinggal 24 jam, konsentrasi rata-rata di dalam influen $901,8 \mathrm{mg} / \mathrm{l}$ sedangkan konsentrasi COD rata-rata di dalam efluen turun menjadi 420,2 mg/l, atau efisiensi penghilangan COD rata-rata menjadi sekitar $62,9 \%$.

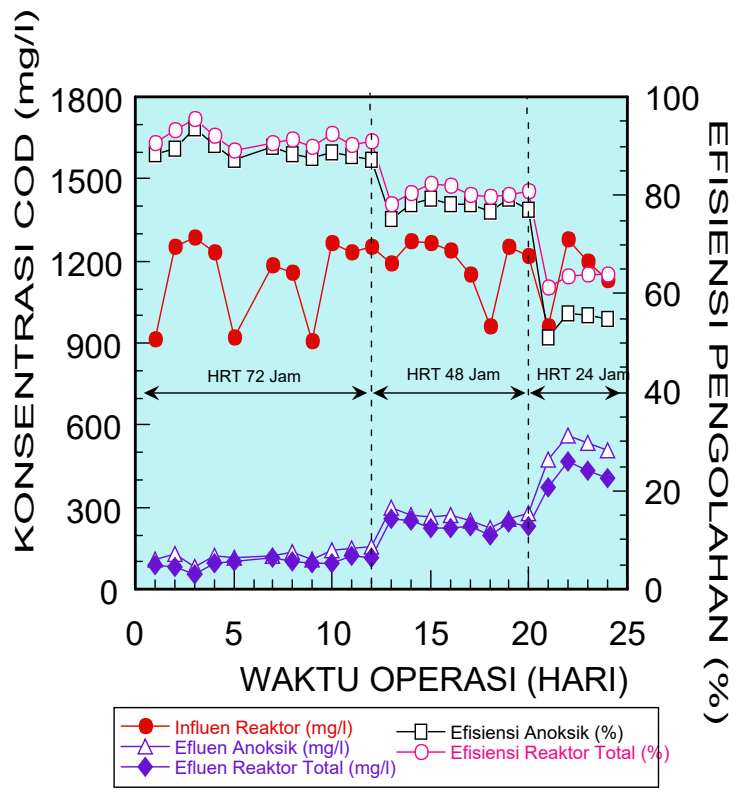

Gambar 6 : Pengaruh waktu tinggal terhadap penurunan konsentrasi dan efisiensi penghilangan COD di dalam reaktor biofilter dengan media bio-ball.

Pada saat penggantian waktu tinggal menjadi lebih pendek terjadi penurunan efisiensi terlebih dahulu dan setelah 2-3 hari barulah mencapai kestabilan. Penurunan efisiensi pada saat penggantian terjadi karena adanya perubahan debit aliran dari pengoperasian sebelumnya (menjadi lebih kecil) sehingga beban hidroliknya pun menjadi lebih besar.
Dari gambar 6 tersebut terlihat bahwa untuk waktu tinggal 72 jam, efisiensi penghilangan senyawa organik (COD) rata-rata pada zona anoksik mencapai hingga $89 \%$, sedangkan efisiensi total (anaerob-aerob) 91,5 $\%$.

Untuk waktu tinggal 48 jam, efisiensi penghilangan senyawa organik (COD) rata-rata pada zona anoksik 77,8 \%, sedangkan efisiensi total (anaerob-aerob) 80,5\%.

Untuk waktu tinggal 24 jam, penghilangan senyawa organik (COD) rata-rata pada zona anoksik 54,5\%, sedangkan efisiensi total (anaerob-aerob) 62,9\%.

Dari hasil tersebut terlihat bahwa dengan proses biofilter anaerob secara efektif dapat menghilangkan zat organik (COD) yang ada di dalam air limbah, sementara zona aerob hanya menyisihkan tidak lebih dari $10 \%$. Hal ini dikarenakan zona anoksik memiliki waktu tinggal yang lebih lama 2 kali lipat daripada zona aerob. Dengan demikian penghilangannya menjadi lebih banyak.

Walaupun demikian, zona aerob tetap diperlukan karena zona aerob juga berguna untuk menurunkan bau dan meningkatkan DO pada efluen akhir. Menurut Rittmann \& Mc Carty (2001), pada reaktor gabungan anoksik-aerob kandungan nitrat dari zona aerob akan diturunkan dengan cara diresirkulasi kembali ke bak influen lalu kemudian terjadi proses denitrifikasi pada zona anoksik.

Dari hasil penelitian tersebut secara keseluruhan menunjukan bahwa semakin pendek waktu tinggal pada reaktor maka semakin menurun pula efisiensi penghilangannya yaitu untuk COD dari $91,5 \%$ pada waktu tinggal 72 jam menjadi hanya $62,9 \%$ pada waktu tinggal 24 jam.

\subsubsection{Penghilangan Zat Padat Tersuspensi (TSS)}

Konsentrasi TSS di dalam air limbah berkisar antara 720 - 1270 mg/l. Pengaruh waktu tinggal terhadap penurunan konsentrasi dan efisiensi penghilangan TSS di dalam reaktor biofilter dengan media bio-ball dapat dilihat seperti pada Gambar 7. Dari hasil tersebut terlihat bahwa dengan waktu tinggal 72 jam sampai dengan 24 jam, efisiensi penghilangan TSS sangat baik yakni mencapai $95 \%-98 \%$. Efisiensi penghilangan TSS pada zona anaerob maupun pada zona aerob tidak menunjukkan perbedaan yang berarti. Hal ini berarti aplikasi bio-ball sebagai media biofilter anaerob maupun biofilter aerob dapat menghilangkan TSS dengan baik. 


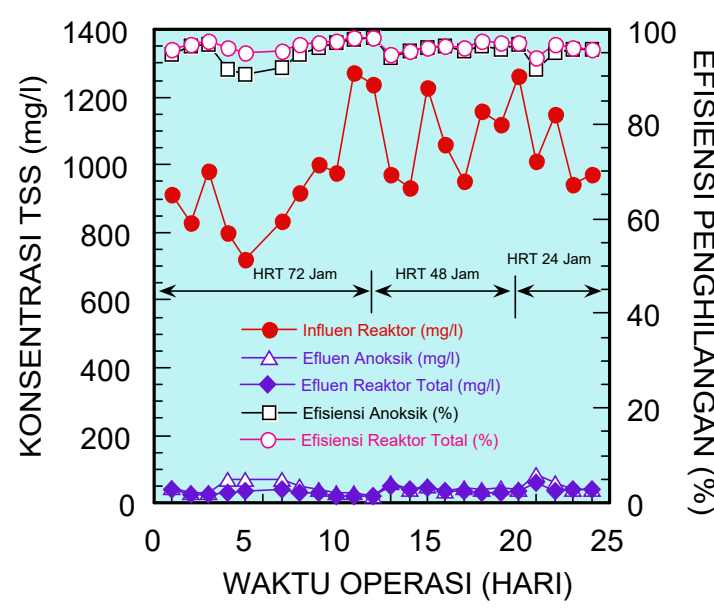

Gambar 7 : Pengaruh waktu tinggal terhadap penurunan konsentrasi dan efisiensi penghilangan TSS di dalam reaktor biofilter dengan media bio-ball.

\subsubsection{Penghilangan Warna}

Efisiensi penghilangan warna di dalam air limbah pencucian jean dengan proses biofilter anaerob-aerob dengan menggunakan media bioball menujukkan kecenderungan yang sama dengan penghilangan zat organik (COD).

Dari hasil tersebut terlihat bahwa untuk percobaan dengan waktu tinggal hidrolis (WTH) 72 jam, konsentrasi warna di dalam influen ratarata 980,6 skala $\mathrm{PtCo}$, sedangkan konsentrasi warna rata-rata di dalam efluen turun menjadi 78,8 skala PtCo, dengan efisiensi penghilangan warna rata-rata $91,8 \%$.

Untuk waktu tinggal hidrolis 48 jam konsentrasi warna di dalam influen rata-rata 1033,9 skala PtCo, sedangkan konsentrasi rata-rata warna di dalam efluen turun menjadi 169,5 skala PtCo, dengan efisiensi penghilangan warna rata-rata menjadi 83,2 \%.

Untuk waktu tinggal 24 jam, konsentrasi warna rata-rata di dalam influen 1118,8 skala PtCo sedangkan konsentrasi warna rata-rata di dalam efluen turun menjadi 572,4 PtCo atau efisiensi penghilangan warna rata-rata menjadi $48,8 \%$. Hasil selengkapnya dapat dilihat seperti pada Gambar 8.

Dari hasil percobaan tersebut di atas dapat dilihat bahwa zona anaerob (anaoksik) dapat menurunkan konsentrasi warna dengan baik, sedangkan zona aerob hanya menyisihkan tidak lebih dari 10\%. Secara keseluruhan dapat disimpulkan bahwa semakin pendek waktu tinggal di dalam reaktor biofilter maka efisiensi penghilangan warna juga semakin kecil. Dengan waktu tinggal 72 jam (3 hari), efisiensi penghilangan warna rata-rata di dalam reaktor biofilter dengan media bio-ball dapat mencapai $91,8 \%$.

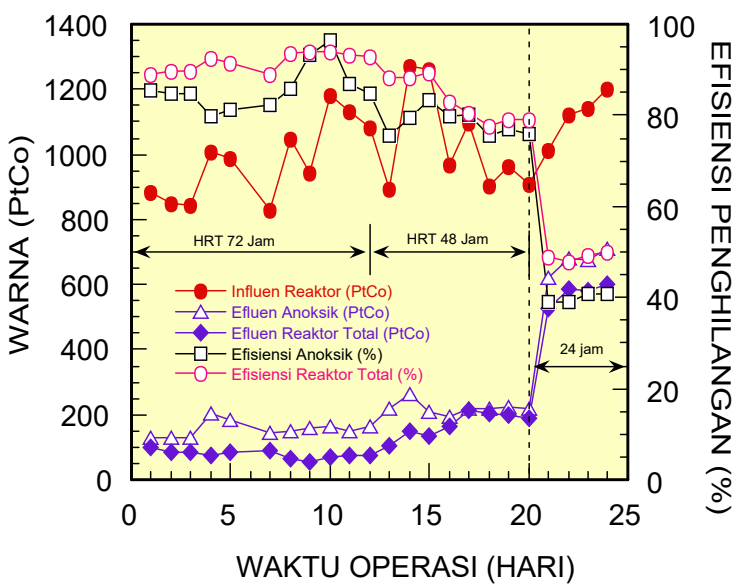

Gambar 8 : Pengaruh waktu tinggal terhadap penurunan konsentrasi dan efisiensi penghilangan warna di dalam reaktor biofilter dengan media bio-ball.

\section{KESIMPULAN}

Berdasarkan hasil percobaan tersebut di atas dapat disimpulkan bahwa :

- Proses biofilter menggunakan media plastik bio-ball dapat digunakan untuk mengolahan air limbah pencucian dan pewarnaan jeans dengan hasil yang baik. Efisiensi penghilangan polutan dipengaruhi oleh waktu tinggal hidrolis di dalam reaktor atau beban pengolahan (beban organik). Semakin lama waktu tinggal hidrolis (WTH) di dalam reaktor biofilter atau semakin besar beban pengolahan (loading) efisiensi penghilangan semakin kecil.

- Pengolahan air limbah industri pencucian jean dengan proses biofilter anaerob-aerob menggunakan media bio-ball dengan kondisi waktu tinggal 1-3 hari di dapatkan efisensi penghilangan COD, BOD, SS dan Warna masing-masing yakni : COD $78-91 \%$, BOD $85-92 \%$, total zat padat tersuspensi (TSS) $80-93 \%$, dan warna $48-57 \%$. Makin kecil waktu tinggal di dalam reaktor biofilter efisiensi penghilangan juga semakain kecil. Pengolahan dengan proses biofilter secara umum dapat menghilangkan polutan organik dan TSS dengan baik, tetapi untuk penghilangan warna kurang efektif. 


\section{DAFTAR PUSTAKA}

- ----"The Study OnUrban Drainage And Waste Water Disposal Project In The City Of Jakarta", , JICA, December 1990.

- ----, " Gesuidou Shissetsu Sekkei Shisin to Kaisetsu “, Nihon Gesuidou Kyoukai, 1984.

- Fair, Gordon Maskew et.al., " Eements Of Water Supply And Waste Water Disposal", John Willey And Sons Inc., 1971.

- Gouda T., " Suisitsu Kougaku - Ouyouben", Maruzen kabushiki Kaisha, Tokyo, 1979.

- Hikami, Sumiko., "Shinseki rosohou ni yoru mizu shouri gijutsu (Water Treatment with
Submerged Filter)", Kougyou Yousui No.411, 12,1992.

- Metcalf And Eddy, "Waste Water Engineering", Mc Graw Hill 1978.

- Sueishi T., Sumitomo H., Yamada K., DAN Wada Y., "Eisei Kougaku " (Sanitary Engineering), Kajima Shuppan Kai, Tokyo, 1987.

- Viessman W, JR., Hamer M.J., "Water Supply And Polution Control ", Harper \& Row, New York,1985.

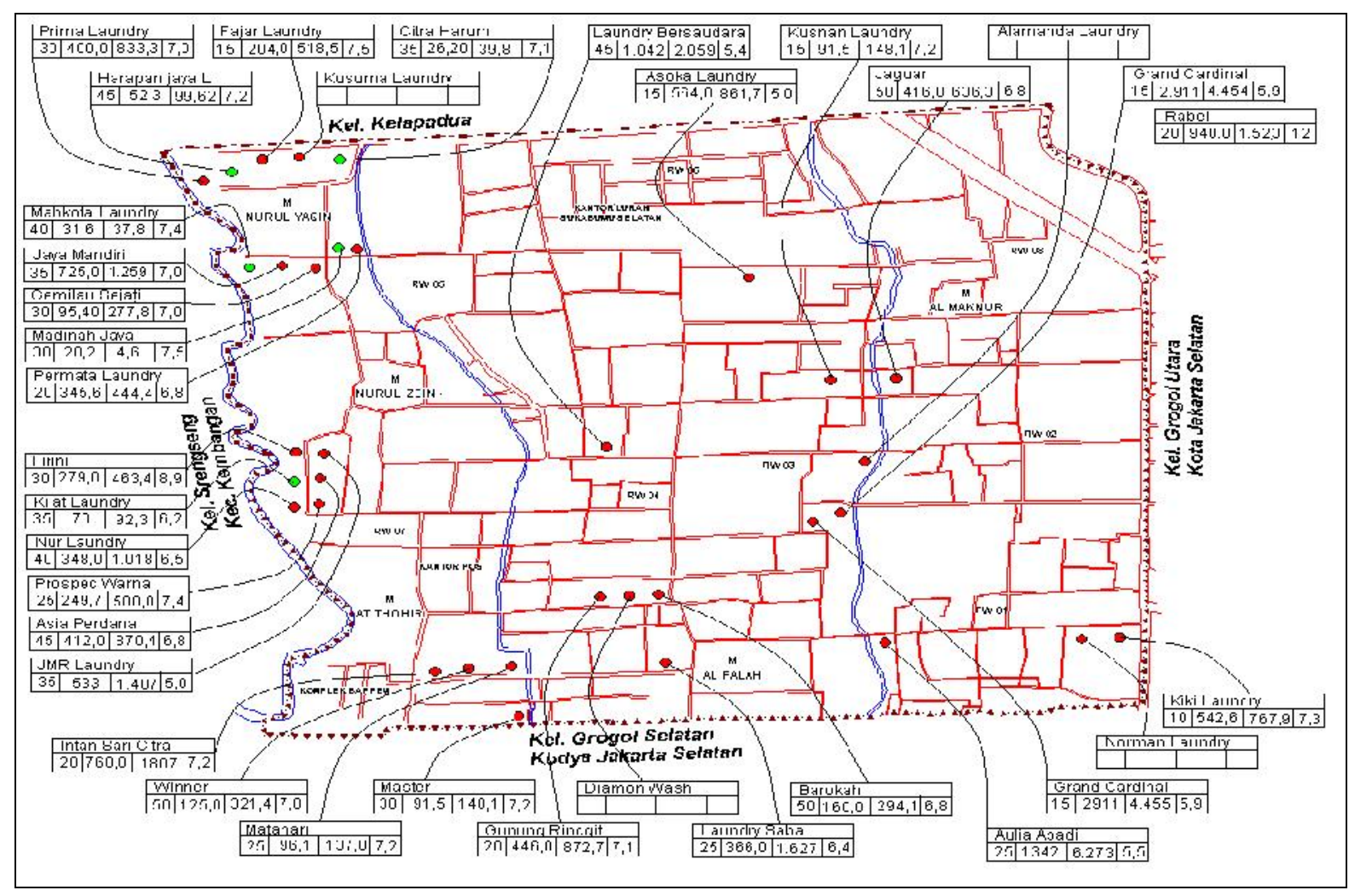

Gambar 1: Lokasi Industri Laundry Di Kelurahan Sukabumi Selatan, Kecamatan Kebon Jeruk, Jakarta Barat.

Keterangan angka di dalam Kotak dari kiri ke kanan : Debit (m3/hari), BOD (mg/l), COD (mg/l) dan pH Air Limbah. 